\title{
Spontaneous approach and apparent play solicitation by a young free-living tayra Eira barbara (Garnivora: Mustelidae) in response to the observer's presence ${ }^{1}$
}

\author{
JOÃO CARNIO TELES DE MENEZES*
}

In a fragment of Atlantic Forest in Eldorado, Mato Grosso do Sul, Central-West Region of Brazil, a juvenile tayra (Eira barbara) spontaneously approached the observer while he was coursing a trail alone. The animal walked in a normal pace and, upon reaching his boots, alternatingly sniffed them and receded afterwards, assuming a posture that much resembles the play bow, a play signal displayed almost exclusively by canids. This is a rare report of a free-living animal that sought interaction with a human in a non-agonistic manner, instead of avoiding it as expected. It may also be one of the few examples of interspecific play in the wild, in case the observed posture was indeed a play bow. Interactions between humans and other animals are usually observed in situations in which the animal is used to the presence of people and often obtains food from these interactions, or when humans are not recognized as threatening by the animal. None of these scenarios seem to explain the observed behavior; individual traits such as boldness or, most likely, exploratoriness, on the other hand, may do so.

Keywords: Human-animal interaction; social play; play bow; interspecific play; animal individuality; Brazil; Atlantic Forest.

Em um fragmento de Mata Atlântica em Eldorado, Mato Grosso do Sul, Centro-Oeste do Brasil, testemunhou-se a aproximação espontânea de uma irara (Eira barbara) jovem ao observador. Ao alcançar suas botas, alternadamente as cheirava e depois recuava, assumindo uma postura muito semelhante ao play bow, utilizado quase exclusivamente por canídeos como sinal de brincadeira. Trata-se de um raro relato em que o animal procurou a interação com o humano de maneira não agonística, ao invés de evitála como seria esperado. Pode ser também um dos poucos exemplos de brincadeira interespecífica na natureza, caso a postura observada seja de fato um play bow. Interações entre humanos e outros animais são comumente observadas quando o animal está acostumado com a presença de pessoas e frequentemente obtém recompensas dessas interações, ou quando humanos não são reconhecidos como ameaça pelo animal. Nenhuma dessas situações parece explicar o comportamento observado, enquanto traços individuais, como coragem e, principalmente, tendência a explorar, podem.

Palavras-chave: Interação animal-humano; brincadeira social; play bow; brincadeira interespecífica; individualidade animal; Brasil; Mata Atlântica.

Interactions between humans and other animals are commonly observed in situations in which the animal is perfectly used to human presence or even imprinted onto them, such as in owner-pet and zookeeper-captive animal relationships. Tayras in captivity interact with their handlers by following them, nibbling their boots and jumping to reach for objects in their hands (Pereira \&
Oliveira, 2010). In areas with a high flow of people, wild animals may also get used to humans and interact with them, mostly with the purpose of getting food (e.g., Bonatti, 2006; Chauhan \& Pirta, 2010; Grossberg, Treves \& Naughton-Treves, 2003; Vieira, 2011).

Play is a behavior displayed by many species of mammals and birds (Bekoff \& Allen, 1998) - for

\footnotetext{
The author is grateful to dr. Marc Bekoff, dr. Maria Adélia B. de Oliveira and dr. Steven J. Presley for providing valuable insights to the interpretation of the behavior described here, and to the two anonymous reviewers whose suggestions greatly improved the final version of this note.

* Centro de Ciências Biológicas e da Saúde, Universidade Presbiteriana Mackenzie, Rua da Consolação, 930, 01302-090, São Paulo, SP, Brasil. E-mail: jocateme@gmail.com
} 
a comprehensive list, see Fagen (1981, pp. 220-247). While social play, i.e., play directed towards another living being (Bekoff \& Allen, 1998), is often observed among animals in captivity, notably including tayras (Fagen, 1981; Fernandes, Santino \& Oliveira, 2011; Pereira \& Oliveira, 2010), those in the wild are not known to spend much time on it, and do so mostly during infant and juvenile life (Bekoff, 2014; Fagen, 1981).

Tayras (Eira barbara) are medium-sized mustelids that occur in Neotropical forests from Southern Mexico to Northern Argentina (Presley, 2000). In Brazil, they occupy a variety of habitats, preferring dense vegetation but also tolerating human-disturbed environments (Cheida et al., 2006; Presley, 2000). Essentially diurnal, their diet is composed by a range of food resources, such as small and medium-sized mammals, reptiles, birds, arthropods, honeycombs and various fruits (Sigrist, 2012; Soley, 2012).

The behavior described below took place in a $1.25 \mathrm{~km}^{2}$ fragment $\left(23^{\circ} 49^{\prime} 37^{\prime \prime} \mathrm{S}, 5^{\circ} 15^{\prime} 59^{\prime \prime} \mathrm{W}\right)$ of seasonal semi-deciduous forest in the municipality of Eldorado, state of Mato Grosso do Sul (MS), in Central-West Brazil. Elevation is 295 masl and climate in Köppen classification is Cfa, i.e., humid subtropical with hot summers and no dry season (Instituto do Meio Ambiente, 2012).

On 10 July of 2008, at 07:51, a tayra actively approached the observer when he was coursing a trail alone. The individual was a juvenile, as indicated by its estimated nose-to-tail length of $74 \mathrm{~cm}$, while adult tayras are 93 to $115 \mathrm{~cm}$ long (Sigrist, 2012). After making itself visible, the animal walked straight towards the observer in a normal pace for approximately 9 meters, while constantly snorting and sniffing with the nose either lowered to the ground or lifted in the air. As it reached the observer's feet, the tayra would alternatingly sniff his boots (Figure 1A) and quickly recede afterwards, assuming a position in which its front legs were lowered and stretched, and the torso drawn back (Figure 1B). This sequence was repeated a few times during approximately 20 seconds of interaction. The observer displayed no reaction that could prolong the encounter.

The reaction one would normally expect to be displayed by a small free-living mammal upon the encounter with a human is to recognize them as a predator and execute a last resource anti-predatory behavior, which mostly involve escape actions from potential predators (Caro, 2005). Wild tayras have been observed fleeing after noticing human presence
(Camargo \& Ferrari, 2006; Menezes, unpublished data), which leads to the following question: what drove this young individual to spontaneously approach the observer and actively interact with him in a non-agonistic manner, instead of fleeing, as expected?

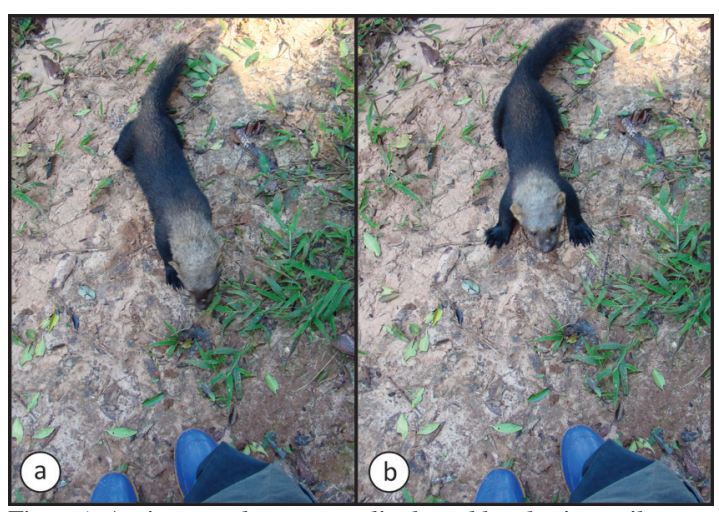

Figure 1. Actions and postures displayed by the juvenile tayra after spontaneously approaching the observer: (a) walking towards him in order to sniff his boots; (b) receding from the observer and assuming a posture similar to the play bow.

As noted before, human-animal interactions in the wild are known to occur in crowded areas such as parks near heavily populated areas (Bonatti, 2006; Vieira, 2011) and/or with high tourist influx (Grossberg, Treves \& Naughton-Treves, 2003), where animals get used to the presence of people as they often obtain food from them. The rural zone of Eldorado (MS), however, is sparsely inhabited 2.7 people per km2 (Miranda, Gomes \& Guimarães, 2005) -, and has low, if any, tourist influx according to personal observation.

Another possibility would be that tayras do not recognize humans as a threat. For this to be real, though, one would expect a harmonic cohabitation between tayras and humans, which seems unlikely to happen in that area. Although no quantitative data is available, illegal hunting is known to take place in the region, as evidenced by local testimonials and several traces of hunting activity found by chance by the author. Whether or not tayras are among the most targeted animals by hunters is unknown, but hunting of this species is recognized as a potential threat to their populations (Rodrigues, Pontes \& Rocha-Campos, 2013) and has been reported in Southeastern Brazil (Pianca, 2004).

The most plausible explanation, thus, lies on individuality, which generally plays an important 
role in animal behavior (Barash, 1997). Tayras in captivity had different individual characteristics that impacted on how they would interact with conspecifics as well as with the handler (dr. Maria Adélia Oliveira, personal communication, 9 June of 2014). Réale et al. (2007), classified traits that are variable among individuals of the same species into five major categories. The trait potentially responsible for the behavior described here could either be part of the "shyness-boldness" category, comprehending reactions displayed by animals when faced with a risky situation, such as encounters with predators and humans, or the "exploration-avoidance" category, which encompasses reactions to new situations, being these risky or not. Given that the individual was young and possibly had never faced a human before, it is likely that its exploiter character drove this behavior, otherwise its bold character could be considered responsible.

The actions displayed by the young tayra make it quite reasonable to infer this interaction was an attempt to engage in dyadic social play. The posture assumed in Figure 1B, as confirmed by dr. Marc Bekoff (personal communication, 9 June of 2014), much resembles an action performed by canids known as bow, which is characterized by them crouching on their forelimbs and elevating their hindquarter (Bekoff, 1974).

By definition (Bekoff \& Byers, 1981), animal play is a blend of actions from other contexts (such as predatory, mating and agonistic) used in modified forms. The bow, however, is a stereotyped action used almost exclusively in the context of social play, as a signal of intention to engage in, or maintain a play episode (Bekoff, 1974, 1995). Therefore, if a bow was indeed displayed by the tayra, it is very unlikely that it could mean anything else but a play solicitation. While different species use different signals to engage in play and some of them, such as the play face, are nearly universal (Fagen, 1981; Oliveira, 2005), this particular one, the bow, apparently has only been described among canids (Bekoff, 1974, 1977) and lions (Schaller, 1972).

Assuming that this behavior was indeed an attempt to initiate social play, it should be considered a rare example of interspecific play in the wild. Examples of this phenomenon include mainly primates, but also rodents, carnivores, artiodactyls, pinnipeds, diprotodonts (Watson, 1998) and birds - for a list, see Fagen (1981, pp. 446-447). Fagen (1981) describes this kind of interaction as rare in nature for reasons such as that it would require insterspecific communication, i.e., the ability of one species to recognize and respond to play signals of another species, and extreme self-handicapping (see Bekoff, 2014) to make the bout stable, given the differences in preferred content of play, and body size and shape.

As human involvement in this interaction may incline one to think it rather resembles those observed between a pet and its owner, or a zoo animal and its handler, it is important to emphasize two aspects: the interaction occurred in the wild and in an area where tayras are probably not used to humans; and the attempt to engage in the interaction (regardless of whether or not it was a play display) was fully initiated and maintained by the tayra, with no reaction by the observer. It is, thus, more comparable to an interaction between two wild animals than one between a human and a tame animal.

The behavior described here exposed the animal to a possible threat, as no anti-predatory defense was shown towards a potentially predatory species. It is of some concern to the populations of tayras if other individuals share the traits that probably drove the behavior of this individual. It is important, therefore, that more attention is directed to the social behaviors of this species.

\section{References}

Barash, D. P. (1997).In search of behavioral individuality. Human Nature, 8, 153-169.

Bekoff, M. (1974). Social play and play-soliciting by infant canids. American Zoologist, 14, 323-340.

Bekoff, M. (1977). Social communication in canids: evidence for the evolution of a stereotyped Mammalian display. Science, 197, 1097-1099.

Bekoff, M. (1995). Play signals as punctuation: the structure of social play in canids. Behaviour, 132, 419-429.

Bekoff, M. (2014). The significance of ethological studies: playing and peeing. In A. Horowitz (Ed.), Domestic Dog Cognition and Behavior (pp. 59-75). Berlin, Germany: Springer.

Bekoff, M., \& Allen, C. (1998). Intentional communication and social play: how and why animals negotiate and agree to play. In M. Bekoff, \& J. A. Byers (Eds.), Animal 
play: evolutionary, comparative, and ecological perspectives (pp. 97-114). Cambridge, England: Cambridge University Press.

Bekoff, M., \& Byers, J. A. (1981). A critical reanalysis of the ontogeny and phylogeny of mammalian social and locomotor play: an ethological hornet's nest. In K. Immelmann, G. W. Barlow, L. Petrinovich, \& M. Main (Eds.), Behavioral Development. New York, NY: Cambridge University Press.

Bonatti, J. (2006). Uso e seleção de hábitat, atividade diária e comportamento de Nasua nasua (Linnaeus, 1766) (Carnivora; Procyonidae) na ilha do Campeche, Florianópolis, Santa Catarina. (Tese de Mestrado). Instituto de Biociências, Universidade Federal do Rio Grande do Sul, Porto Alegre, RS.

Camargo, C. C., \& Ferrari, S. F. (2007). Interactions between tayras (Eira barbara) and red-handed howlers (Alouatta belzebul) in eastern Amazonia. Primates, 48, 147-150.

Caro, T. (2005). Antipredator defenses in birds and mammals. Chicago, IL: University of Chicago Press.

Chauhan, A., \& Pirta, R. S. (2010). Agonistic interactions between humans and two species of monkeys (rhesus monkey Macaca mulatta and hanuman langur Semnopithecus entellus) in Shimla, Himachal Pradesh. fournal of Psychology (India), 1, 9-14.

Cheida, G. C., Nakano-Oliveira, E., Fusco-Costa, R., Rocha-Mendes, F., \& Quadros, J. (2006). Ordem Carnivora. In N. R. Reis, A. L. Peracchi, W. A. Pedro \& I. P. Lima (Eds.), Mamíferos do Brasil (pp. 231-276). Londrina, PR: Universidade Estadual de Londrina.

Fagen, R. (1981). Animal play behavior. New York, NY: Oxford University Press.

Fernandes, G. A. A., Santino, M. B., \& Oliveira, M. A. B. (2011). Análise comportamental do Eira barbara em cativeiro no Zoológico do Parque Estadual de Dois Irmãos. In B. T. R. V. Brasileiro (Org.), Anais do I Congresso Nacional de Ciências Biológicas (pp. 77-83). Recife, PE: Universidade Católica de Pernambuco.

Grossberg, R., Treves, A., \& Naughton-Treves, L. (2003). The incidental ecotourist: measuring visitor impacts on endangered howler monkeys at a Belizean archaeological site. Environmental Conservation, 30, 40-51.
Instituto de Meio Ambiente do Mato Grosso do Sul. (2012). Avaliação ambiental estratégica do Prodetur Nacional no Estado do Mato Grosso do Sul: diagnóstico. Campo Grande, MS: IMASUL.

Miranda, E. E., Gomes, E. G., \& Guimarães, M. (2005). Mapeamento e estimativa da área urbanizada do Brasil com base em imagens orbitais e modelos estatísticos. Campinas, SP: Embrapa Monitoramento por Satélite. Retrieved from http://www.urbanizacao. cnpm.embrapa.br.

Oliveira, C. R. (2005) Comportamento de brincadeira em micosleões-dourado (Leontopithecus rosalia Linnaeus, 1766): ontogenia, aspectos sociais e interações interespecíficas. (Tese de Doutorado). Faculdade de Filosofia, Ciências e Letras, Universidade de São Paulo, Ribeirão Preto, SP.

Pereira, R. L. A., \& Oliveira, M. A. B. (2010). Etograma do Eira barbara (Carnivora: Mustelidae) em cativeiro. Revista de Etologia, 9, 45-57.

Pianca, C. C. (2004). A caça e seus efeitos sobre a ocorrência de mamíferos de médio e grande porte em áreas preservadas de Mata Atlântica na Serra de Paranapiacaba, São Paulo. (Dissertação de Mestrado). Escola Superior de Agricultura "Luiz de Queiroz", Universidade de São Paulo, Piracicaba, SP.

Presley, S. J. (2000). Eira barbara. Mammalian Species, 636, $1-6$.

Réale, D., Reader, S. M., Sol, D., McDougall, P. T., \& Dingemanse, N. J. Integrating animal temperament within ecology and evolution. Biological Revieres, 82, 291-318.

Rodrigues, L. A., Pontes, A. R. M., \& Rocha-Campos, C. C. (2013). Avaliação do risco de extinção da irara Eira barbara (Linnaeus, 1758) no Brasil. Biodiversidade Brasileira, 3, 195-202.

Schaller, G. B. (1972). The Serengeti lion: a study of predatorprey relations. Chicago, IL: University of Chicago Press.

Sigrist, T. (2012). Mamíferos do Brasil: uma visão artística. Vinhedo, SP: AvisBrasilis.

Soley, F. G. (2012). Notes on the flexibility of foraging behaviour in tayras Eira barbara. Small Carnivore Conservation, 46, 33-35. 
Approach and play solicitation by a young free-living tayra

Vieira, P. A. (2011). Interação entre humanos e macacos-pregos Cebus libidinosus Spix, 1823 sob a influência de ambientes antropizados. (Dissertação de Mestrado). Instituto de Ciências Biológicas, Universidade Federal de Goiás, Goiânia, GO.
Watson, D. M. (1998). Kangaroos at play: play behaviour in the Macropodoidea. In M. Bekoff, \& J. A. Byers (Eds.), Animal Play: evolutionary, comparative, and ecological perspectives (pp. 61-96). Cambridge, England: Cambridge University Press. 